\title{
Intracytoplasmic Lipofuscin Present
}

National Cancer Institute

\section{Source}

National Cancer Institute. Intracytoplasmic Lipofuscin Present. NCI Thesaurus. Code C96268.

A morphologic finding indicating the presence of fine granular yellowish-brownish pigment within the cytoplasm of the cells in a tissue sample. 